\title{
IDENTYFIKACJA CZYNNIKÓW ORAZ SZACOWANIE RYZYKA W PROJEKCIE ORGANIZACJI IMPREZ SPORTOWYCH
}

DOI: $10.33141 /$ po.2020.11.05

\author{
Jacek Łuczak, Małgorzata Miśniakiewicz
}

Przegląd Organizacji, Nr 11(970), 2020, s. 33-40

www.przegladorganizacji.pl

๑) Towarzystwo Naukowe Organizacji i Kierownictwa (TNOiK)

\section{Wprowadzenie}

B ieganie to jeden $\mathrm{z}$ niewielu sportów charakteryzujących się brakiem barier, pozwalających na spełnienie własnych ambicji niezależnie od wieku, płci, statusu społecznego czy poziomu wykształcenia (Petridis, 2015, s. 141). Obserwowany w ostatnich latach wzmożony wzrost zainteresowania bieganiem znajduje potwierdzenie $\mathrm{w}$ dostępnych danych liczbowych - tylko w latach 2010-2015 odnotowano w Polsce 650\% wzrost liczby biegaczy, co według badań CBOS plasuje Polskę na pierwszym miejscu pod względem odsetka biegaczy amatorów wśród krajów Europy Środkowej i Wschodniej. Niewątpliwie mamy do czynienia z modą, efektem naśladownictwa, formą ekspresji indywidualizmu, dążeniem do intensywnej aktywności fizycznej w możliwie długim okresie życia, chęcią sprawdzenia się i rywalizacji (Czkór, 2014, s. 40). Wyniki badań wskazują, że większość biegaczy w ciągu niecałego roku od rozpoczęcia regularnych treningów zaczyna biernie, a następnie aktywnie uczestniczyć w zorganizowanych imprezach biegowych (Dzięgiel, Lubowiecki-Vikuk, 2013, s. 122; Hitchings, Latham, 2017, s. 340).

W ciągu ostatnich kilku lat liczba masowych biegów długodystansowych organizowanych $\mathrm{w}$ Polsce istotnie wzrosła - w 2010 r. zarejestrowano blisko 800 imprez biegowych, a w 2017 r. - 2500. Dwanaście największych półmaratonów w Polsce w 2018 roku ukończyło w sumie 76593 biegaczy, co oznacza wzrost o prawie $60 \%$ w porównaniu do 2014 roku. Warto jednak podkreślić, że mapę biegową Polski budują zarówno maratony i półmaratony, jak i setki mniejszych imprez biegowych (www.maratony polskie.pl, 2019).

Wzrost liczby wydarzeń sportowych doprowadził do wyraźnego konkurowania organizatorów o uczestników, przyczyniając się do dążenia przez nich do poprawy jakości oraz efektywności imprez, a tym samym profesjonalizacji ich organizacji (Shipway i in., 2013, s. 261).

Bez względu na skalę i dystans biegu imprezy masowe budzą wiele emocji i wiążą się $\mathrm{z}$ dużymi oczekiwaniami organizatorów, uczestników, widzów i sponsorów. Ich złożoność wynika z wymogów prawnych i formalnych, specyfiki terenu, warunków pogodowych, poziomu finansowania (Leopkey, Parent, 2009a, s. 189). Specyfika imprezy biegowej wynika również z ograniczonej możliwości wprowadzania zmian w czasie jej trwania, różnorodności i liczby uczestników, ich poziomu sportowego, a także ze ściśle określonego i limitowanego czasu i daty wyda- rzenia (Scheerder i in., 2015a; 2015b). W konsekwencji profesjonalne zarządzanie imprezą sportową wydaje się elementem niezbędnym do efektywnego nią zarządzania (Piekarz i in., 2015). To na organizatorze spoczywa odpowiedzialność określenia potencjalnego ryzyka w czasie biegu oraz implikacja adekwatnych środków do ich kontrolowania. Jednak, jak wynika z badań własnych autorów, aż 51\% organizatorów imprez sportowych w Polsce nie prowadzi formalnego zarządzania projektem zgodnie z uznaną metodyką, przy czym $78 \%$ szacuje ryzyko organizacji nieformalnie, co $\mathrm{w}$ praktyce ogranicza się do intuicyjnego unikania zagrożeń i spełniania istniejących wymogów prawnych. Istnieje zatem duże prawdopodobieństwo, że decyzje związane $\mathrm{z}$ organizacją imprezy nie będą optymalne, ponieważ nie zidentyfikowano znaczących elementów ryzyka i w związku z tym nie zostały one odpowiednio złagodzone (Hanstad, 2012, s. 190). To z kolei może skutkować odniesieniem mniejszych niż zakładano korzyści, przerwaniem imprezy lub zakłóceniem jej przebiegu (Reid, Ritchie, 2011, s. 331), a w konsekwencji prowadzić do utraty reputacji organizatora i niezadowolenia uczestników. Co więcej, zarządzanie ryzykiem wydaje się kluczowe, skoro na trasie zdarzają się wypadki śmiertelne, a udział w wydarzeniu sportowym nie wymaga od biegacza ani doświadczenia, ani zaświadczenia o dobrym stanie zdrowia.

Biorąc powyższe pod uwagę, celem niniejszej pracy była identyfikacja czynników ryzyka oraz dokonanie szacowania ryzyka w odniesieniu do półmaratonów organizowanych w Polsce w 2017 r. z uwzględnieniem wytycznych normy ISO 31000. Stanowi to istotny element zarządzania projektami, tu organizacji imprez sportowych. Rezultat szacowania ryzyka powinien stanowić podstawę planu i działań związanych z projektem, co pozwoli na zapewnienie skuteczności w osiąganiu celów imprezy (m.in. zapewnienie bezpieczeństwa uczestników).

W pracy postawiono hipotezy badawcze:

1. Pośród czynników ryzyka istotnych dla zarządzania ryzykiem organizacji imprez sportowych są te dotyczące zagrożeń terrorystycznych, bezpieczeństwa finansowego, danych osobowych oraz aspektów społecznych.

2. Najistotniejsze ryzyka związane $\mathrm{z}$ organizacją imprez biegowych dotyczą budżetu, jakości i bezpieczeństwa trasy oraz terroryzmu. 


\section{Zarządzanie projektami organizacji imprez sportowych}

0 rganizacja biegów długodystansowych wymaga profesjonalnego przygotowania $\mathrm{w}$ zakresie planowania i realizacji z wykorzystaniem określonych koncepcji, a przynajmniej jej elementów. Mogą to być metodyki o charakterze tradycyjnym, np. Prince2, PMBook czy zyskujące coraz większą popularność i adaptowane coraz częściej poza projekty IT podejścia zwinne, np. Agile Scrum (Spałek, 2018, s. 156; Beck i in., 2001; Helms, 2011; Łuczak, Miśniakiewicz, 2011, s. 184; Idzikowski, Głowicki, 2016, s. 21).

Zarządzanie ryzykiem przywoływane w metodykach zarządzania projektami znajduje swoje podstawy m.in. w międzynarodowym standardzie ISO 31000. Przedstawia kompleksowe zasady i wytyczne, pomaga organizacjom w dokonywaniu analizy ryzyka oraz oceny ryzyka. Zalecenia najlepszych praktyk, zawarte $\mathrm{w}$ niniejszym standardzie, zostały tak opracowane, by usprawnić techniki zarządzania i zapewniać bezpieczeństwo realizacji projektów. Zarządzanie ryzykiem wg ISO 31000 obejmuje m.in. identyfikację ryzyka, ocenę i ewaluację ryzyka, postępowanie z ryzykiem oraz jego monitorowanie i związaną z nimi komunikację. Jednym $\mathrm{z}$ celów powstania normy jest integracja procesu zarządzania ryzykiem $z$ procesami zarządzania organizacją, a także z jej strategią i planowaniem, zarządzaniem, procesami raportowania, politykami, wartościami i kulturą. Ogólne podejście określone w ISO 31000 dostarcza zasad i wytycznych do zarządzania jakimkolwiek rodzajem ryzyka w sposób systematyczny, przejrzysty i wiarygodny w obrębie dowolnego zakresu i kontekstu.

Analiza literatury przedmiotu nie wskazuje na specyficzne sprofilowanie kluczowych definicji dotyczących projektów i zarządzania projektami. Projekt to zadanie jednorazowe o zdefiniowanym czasie trwania, przydzielonych niezbędnych zasobach i określonym celu jego realizacji. Zarządzanie projektami natomiast definiowane jest jako czynność, przy której stosujemy zdobytą wiedzę, umiejętności, narzędzia oraz techniki w celu realizacji określonych celów i spełnienia wymagań danego projektu (Ammon, Brown, 2007, s. 289). E. Bukłaha (2019, s. 220 -225) zwraca uwagę na istotną rolę zarządzania ryzykiem oraz nadzór $\mathrm{w}$ procesie zarządzania projektami. P. Wyrozębski (2019, s. 220-228) uważa wiele elementów za konieczne, m.in. utrzymywanie kapitału intelektualnego, koordynacja i centralizacja projektów, doskonalenie praktyk i rezultatów zarządzania projektami, a także podejście oparte na ryzykach.

W przypadku organizacji imprez sportowych profesjonalne zarządzanie projektem powinno składać się z następujących elementów:

- planowanie imprezy sportowej (cele i zadania, identyfikacja rynku, harmonogram, budżetowanie i opcje finansowe, niezbędne pozwolenia i zgody, planowanie awaryjne),

- zarządzanie imprezą (wolontariusze, marketing i media, zarządzanie ryzykiem),

- ocena imprezy (uczenie się na doświadczeniu) (Shipway i in., 2013, s. 263).
Coraz większa konkurencja pomiędzy imprezami sportowymi rozgrywającymi się w tym samym czasie wymaga ich nieustannej modyfikacji - uatrakcyjniania i profesjonalizacji - w zakresie zabezpieczenia, możliwości bicia rekordów życiowych (imprezy biegowe), dostępu widzów i obserwatorów (np. śledzenie wyników on-line w aplikacji) (Idzikowski, Głowicki, 2016, s. 26-28).

A. Albrecht (2014, s. 68-69) zwraca uwagę, że imprezy sportowe organizowane dla amatorów niosą $\mathrm{z}$ sobą określone zagrożenia, np. słabe przygotowanie kondycyjne uczestników i związane z tym ryzyka. Podkreśla rolę koncepcji logistyki imprez sportowych jako wiodącego elementu zarządzania projektami - bazowanie na szacowaniu ryzyka. Wskazuje również, że priorytetem organizatora imprez sportowych musi być bezpieczeństwo zawodników i kibiców. Organizator musi być przygotowany na nieprzewidziane sytuacje wynikające $\mathrm{z}$ zakwaterowania, transportu obsługi zawodów. J. Miller i inni (2010, s. 114-116) za element kluczowy uznają odpowiednie zarządzanie ryzykiem w przygotowaniu projektów imprez sportowych, określając je jako podstawę do osiągnięcia celów i zapewnienia bezpieczeństwa uczestników. Jednak oszacowanie ryzyka, a nawet podejmowanie działań mitygujących wobec ryzyk nieakceptowalnych, nie jest wystarczające. Niezbędne jest opracowanie i wdrożenie procedur zarządzania imprezą wskazujących na akceptację wszystkich czynników ryzyka oraz planów działań wobec sytuacji kryzysowych.

\section{Szacowanie ryzyka imprez sportowych}

$T$ ermin ryzyko pochodzi od łacińskiego słowa „riscore”, co oznacza - odważ się i sugeruje, że powinno być postrzegane jako świadomy wybór, a nie konieczność (Boo, Gu, 2010, s. 140). W normie ISO 31000 definiowane jest jako wpływ niepewności na cele (ISO 31000,2012 , s. 15). Ryzyko może być traktowane „jako zagrożenie lub jakiekolwiek przyszłe zdarzenie, które negatywnie wpłynie na wydarzenie" (Bowdin i in., 2006, s. 318), lub neutralnie jako narzędzie pozwalające na „zminimalizowanie zobowiązań i maksymalizacje szans" (Silvers, 2008, s. 22).

Zgodnie z normą ISO 31000, zarządzanie ryzykiem to skoordynowane działanie dotyczące kierowania i nadzorowania organizacji w odniesieniu do ryzyka. Zarządzanie ryzykiem obejmuje zatem określenie kontekstu, ocenę ryzyka (w tym identyfikację ryzyka, analizę i ocenę) oraz sposób traktowania z ryzykiem. Szacowanie ryzyka jest elementem koniecznym dla podejmowania działań mitygujących (ISO 31000), a samo zarządzanie ryzykiem ma charakter proaktywny, bowiem jego celem jest kontrolowanie nieprzewidzianych zdarzeń (Hanstad, 2012, s. 190; Łuczak, Miśniakiewicz, 2011, s. 184).

Szacowanie, i szerzej zarządzanie ryzykiem, w zarządzaniu projektami jest przedmiotem dociekań wielu autorów. J. Chadam (2016, s. 34-40) podkreśla podział ról $\mathrm{w}$ realizacji projektu inwestycyjnego i rozproszenie ryzyk oraz wynikające $\mathrm{z}$ tego problemy dotyczące spójności, akceptacji i priorytetów w zakresie mitygacji. 
Zwraca uwagę na decyzje biznesowe dotyczące finansowania oraz ryzyka polityczne. E. Głodziński (2014, s. 35-38) koncentruje się w swoich badaniach na konieczność równoważnego traktowania działań wyprzedzających, nie tylko mitygujących zidentyfikowane ryzyko. Niesie to konieczność monitorowania przez zespoły projektowe zarówno kwantyfikowanych szans/ryzyk, jak i niemierzalnych w chwili oceny potencjałów/zagrożeń. Sugeruje metodyczne - znacznie szersze postrzeganie zarządzania ryzykami w ramach zarządzania projektami, co dawałoby kluczową podstawę sukcesu. T.A. Grzeszczyk (2016, s. 97-99), skupiając się na projektach publicznych, zwraca uwagę na zewnętrzne czynniki ryzyka, na które nie mają wpływu menedżerowie, stąd konieczność modyfikacji stosowanych metodyk oceny ryzyka na poziomach makroekonomicznym, mezogospodarczym i mikroekonomicznym.

Zarządzanie ryzykiem $\mathrm{w}$ imprezach sportowych na dużą skalę staje się coraz ważniejsze i powinno być badane $\mathrm{z}$ różnych perspektyw, jednak za jego identyfikację i zarządzanie odpowiedzialni powinni być organizatorzy imprezy (Moyle i in., 2014, s. 97). W literaturze europejskiej rzadko analizowano problem organizacji wydarzeń sportowych oraz szacowania ryzyka z tym związanego. Większość artykułów dostarcza informacji w zakresie zarządzania ryzykiem $\mathrm{w}$ sporcie czy organizacji imprez sportowych, przy czym autorzy koncentrują się na bezpieczeństwie uczestników i kontroli tłumu, urazach i kontuzjach, zarządzaniu infrastrukturą sportową, terroryzmie czy szkodach i roszczeniach spowodowanych $\mathrm{w}$ trakcie imprez sportowych, agresji i chuligaństwie (Leopkey, Parent, 2009a; 2009b; Linton, Valentin, 2018; Toohey, Taylor, 2008; Reid, Ritchie, 2011).

Dostrzegalna jest jednak luka w odniesieniu do imprez masowych (biegowych) organizowanych z myślą o sportowcach amatorach (Łuczak, Miśniakiewicz, 2014, s. 90-91. Chęć wypełnienia tej luki stała się główną intencją autorów. Na celowość podejścia wskazują także inni autorzy, zwracając uwagę na zyskujące popularność lokalne imprezy dla amatorów (Moyle i in., 2014, s. 96-97).

\section{Metoda badawcza}

$\mathbf{Z}$ aplanowano i zrealizowano badanie przygotowawcze (1) oraz badanie właściwe (2), wobec których określono podstawowy cel - identyfikację i oszacowanie ryzyka oraz analizę danych pod kątem określenia kierunków decyzji zarządczych w ramach zarządzania projektem sportowym (organizacją półmaratonów) (tab. 1).

Autorzy przeprowadzili badanie o charakterze przygotowawczym (rok 2017), które pozwoliło na opracowanie badania właściwego (lata 2018 i 2019). Realizując badanie, osiągnięto dwa cele: (1) identyfikację czynników ryzyka organizacji półmaratonów, (2) weryfikację czynników ryzyka oraz grupowanie logiczne (porządkowanie). W efekcie pozwoliło to na przeprowadzenie badania właściwego, którego celem było szacowanie ryzyka zgodnie z przyjętą metodyką oraz analiza uzyskanych danych.

W badaniu przygotowawczym zastosowano metodę delficką (Thangaratinam, Redman, 2005, s. 120-123). Udział w nim wzięło 8 ekspertów z zakresu organizacji imprez sportowych - biegów długodystansowych, doświadczonych uczestników oraz badaczy z zakresu problematyki sportowej i zarządzania projektami. Efektem badania była lista czynników ryzyka pogrupowanych w dziewięciu kategoriach.

Badanie właściwe zostało przeprowadzone $\mathrm{z}$ wykorzystaniem ankiety w latach 2018-2019; czynniki ryzyka były oceniane w skali porządkowej czteropunktowej, pod kątem znaczenia (skutku) oraz prawdopodobieństwa wystąpienia zdarzenia. Szacowania dokonywali przedstawiciele organizatorów, którzy zgodnie $\mathrm{z}$ deklaracją znają wszystkie tajniki organizacji imprezy sportowej. W badaniu uczestniczyło 22 przedstawicieli organizatorów odpowiedzialnych za 9 półmaratonów w Polsce ( $6 \mathrm{z}$ nich z pierwszej 10 najliczniejszych w 2017 r.). Każda impreza była reprezentowana przez 1-3 przedstawicieli. Badanie było wsparte narzędziem informatycznym e-risk, wykorzystywanym $w$ zarządzaniu ryzykiem w wielu organizacjach komercyjnych i publicznych. Zapewnia ono wszechstronną konfigurowalność w odniesieniu do metodyki, czynników ryzyka oraz pełen nadzór

Tabela 1. Charakterystyka badania przygotowawczego (1) i badania wtaściwego (2)

\begin{tabular}{|c|l|l|}
\cline { 2 - 3 } Metoda badawcza, wykonane analizy & Badanie przygotowawcze (1) & Badanie właściwe (2) \\
\hline Narządzie badawcze & Metoda delficka & $\begin{array}{l}\text { Analiza rzetelności, szacowanie ryzyka, analiza } \\
\text { czynnikowa }\end{array}$ \\
\hline Liczność próby & Dyskutowana ankieta badawcza & Kwestionariusz ankietowy \\
\hline Czas realizacji badania & 8 ekspertów & $2018-2019$ \\
\hline Cel badania & 2017 & $\begin{array}{l}\text { Szacowane i analiza ryzyka związana } \\
\text { z organizacją półmaratonów }\end{array}$ \\
\hline $\begin{array}{c}\text { Narzędzia informatonów } \\
\text { forma wykonania badań }\end{array}$ & $\begin{array}{l}\text { Identyfikacja oraz grupowanie czynników } \\
\text { ryzyka organizacji półmaratonów. } \\
\text { Przygotowanie badania właściwego }\end{array}$ & Kontakt email, bezpośrednie spotkania \\
\hline
\end{tabular}

Źródło: opracowanie własne 
Tabela 2. Grupy oraz czynniki ryzyka - rezultat badania przygotowawczego (1)

\begin{tabular}{|c|c|c|}
\hline Grupa 1. Bezpieczeństwo & Grupa 2. Budżet i finanse & Grupa 3. Informacja \\
\hline $\begin{array}{l}\text { 1.1. Poważny incydent na trasie } \\
\text { 1.2. Wtargnięcie osoby postronnej na trasę } \\
\text { biegową } \\
\text { 1.3. Uczestnik o niedostatecznym stanie } \\
\text { zdrowia } \\
\text { 1.4. Kolizja z innymi osobami, przedmiotami, } \\
\text { samochodami itp. na trasie biegowej } \\
\text { 1.5. Atak terrorystyczny } \\
\text { 1.6. Skażenie, celowe zanieczyszczenie } \\
\text { żywności/ napojów dostępnych na trasie/ mecie } \\
\text { zawodów } \\
\text { 1.7. Niedostateczne zabezpieczenie medyczne }\end{array}$ & $\begin{array}{l}\text { 2.1. Zbyt małe wpływy z opłat startowych } \\
\text { 2.2. Zbyt małe wpływy ze środków sponsorów } \\
\text { 2.3. Brak płynności finansowej } \\
\text { 2.4. Brak zysku na zakładanym poziomie } \\
\text { 2.5. Kolizja terminy z inną konkurencyjną } \\
\text { imprezą } \\
\text { 2.6. Wysoka opłata startowa }\end{array}$ & $\begin{array}{l}\text { 3.1. Nieaktualny serwis informacyjny www } \\
\text { 3.2. Brak/niedostateczny kontakt } \\
\text { z potencjalnymi uczestnikami } \\
\text { 3.3. Niedostateczna promocja/ informacja na } \\
\text { zewnętrznych portalach internetowych } \\
\text { 3.4. Niezamierzone ujawnienie danych } \\
\text { osobowych } \\
\text { 3.5. Kradzież danych osobowych } \\
\text { 3.6. Cyberatak - zmiana, zablokowanie serwisu } \\
\text { www } \\
\text { 3.7. Brak czytelnej, interaktywnej mapy trasy } \\
\text { 3.8. Brak szybkiej informacji o wyniku }\end{array}$ \\
\hline $\begin{array}{c}\text { Grupa 4. Komfort i satysfakcja } \\
\text { uczestników }\end{array}$ & Grupa 5. Organizacja & Grupa 6. Pakiet startowy \\
\hline $\begin{array}{l}\text { 4.1. Brak darmowych miejsc noclegowych } \\
\text { 4.2. Zła organizacja przechowalni rzeczy } \\
\text { 4.3. Utrudnienia w dotarciu na start } \\
\text { 4.4. Brak miejsc parkingowych w pobliżu startu } \\
\text { 4.5. Brak możliwości odebrania pakietów } \\
\text { startowych w dniu zawodów } \\
\text { 4.6. Start jednoczesny (nie falami) } \\
\text { 4.7. Zbyt wąska trasa biegowa, przewężenia } \\
\text { 4.8. Brak lub nieczytelna informacja } \\
\text { o przebytym dystansie } \\
\text { 4.9. Nieatrakcyjna trasa } \\
\text { 4.10. Nieatrakcyjne expo, niekorzystna } \\
\text { lokalizacja expo } \\
\text { 4.11. Brak możliwości wzięcia prysznica } \\
\text { po zawodach }\end{array}$ & $\begin{array}{l}\text { 5.1. Błędne oznaczenie trasy biegowej } \\
\text { 5.2. Niedostateczny dostęp WC } \\
\text { 5.3. Nieatrakcyjny catering na mecie } \\
\text { 5.4. Brak możliwości gromadzenia widzów } \\
\text { w strefie startu i mety } \\
\text { 5.5. Niewłaściwa organizacja startu - tłok } \\
\text { po rozpoczęciu biegu } \\
\text { 5.6. Niewłaściwa organizacja mety } \\
\text { 5.7.Brak właściwej atmosfery imprezy } \\
\text { 5.8. Problemy dotyczące organizacji, terminu, } \\
\text { itd. z lokalną społecznością, administracją } \\
\text { 5.9. Opóźniony start } \\
\text { 5.10. Mniejsza niż typowa liczba punktów } \\
\text { żywieniowych } \\
\text { 5.11. Niewłaściwa organizacja punktów } \\
\text { żywieniowych } \\
\text { 5.12. Zbyt mała liczba wolontariuszy } \\
\text { 5.13. Brak zaangażowania wolontariuszy } \\
\text { 5.14. Niesprawny pomiar czasu } \\
\text { 5.15. Brak ustanowionych procedur } \\
\text { 5.16. Ograniczone zasoby personalne } \\
\text { 5.17. Niedostosowanie przepustowości trasy } \\
\text { biegowej do liczby uczestników }\end{array}$ & $\begin{array}{l}\text { 6.1. Nieatrakcyjny pakiet startowy } \\
\text { 6.2. Nieatrakcyjny projekt medalu } \\
\text { 6.3. Zbyt mała liczba medali } \\
\text { 6.4. Zbyt mała liczba pakietów startowych }\end{array}$ \\
\hline $\begin{array}{c}\text { Grupa 7. Regeneracja } \\
\text { i wsparcie energetyczne }\end{array}$ & Grupa 8. Reputacja & Grupa 9. Środowisko i siła wyższa \\
\hline $\begin{array}{l}\text { 7.1. Brak możliwości masażu w strefie finiszu } \\
\text { 7.2. Brak właściwego nawodnienia zawodników } \\
\text { 7.3. Niedostateczna ilość wody w ramach } \\
\text { punktów regeneracji } \\
\text { 7.4. Niedostateczna ilość napojów } \\
\text { izotonicznych w ramach punktów regeneracji } \\
\text { 7.5. Niedostateczna liczba żeli energetycznych, } \\
\text { owoców itd. w ramach punktów regeneracji } \\
\text { 7.6. Przypadkowy dobór produktów } \\
\text { żywieniowych i napojów w punktach } \\
\text { regeneracji i na mecie } \\
\text { 7.7. Niska jakość zdrowotna oferowanych } \\
\text { produktów żywnościowych, regeneracyjnych } \\
\text { 7.8. Brak świadomości żywieniowej } \\
\text { zawodników } \\
\text { 7.9. Brak wsparcia dietetyka } \\
\text { 7.10. Brak/ niewystarczająca liczba punktów } \\
\text { chłodzenia organizmu na trasie }\end{array}$ & $\begin{array}{l}\text { 8.1. Nieprzychylne informacje medialne } \\
\text { o zasięgu ogólnokrajowym } \\
\text { 8.2. Nieprzychylne informacje medialne } \\
\text { o zasięgu lokalnym } \\
\text { 8.3. Brak informacji medialnych o imprezie } \\
\text { w mediach ogólnokrajowych } \\
\text { 8.4. Brak informacji medialnych o imprezie } \\
\text { w mediach lokalnych } \\
\text { 8.5. Zbyt mała liczba uczestników } \\
\text { 8.6. Konkurencyjna impreza lokalna }\end{array}$ & $\begin{array}{l}\text { 9.1. Ulewny deszcz } \\
\text { 9.2. Porywisty wiatr } \\
\text { 9.3. Zbyt niska temperatura } \\
\text { 9.4. Zbyt wysoka temperatura } \\
\text { 9.5. Trudne warunki trasy biegowej } \\
\text { 9.6. Ruch uliczny w bezpośredniej bliskości } \\
\text { imprezy } \\
\text { 9.7. Siła wyższa }\end{array}$ \\
\hline
\end{tabular}

Źródło: opracowanie wtasne 
nad aktywnością uczestników badania (e-risk.pl, 2018). Wszystkie półmaratony odbywały się w Polsce na terenie płaskim i umiarkowanym oraz miały charakter biegów miejskich, dzięki czemu uzyskano podobną charakterystykę pod kątem m.in. warunków klimatycznych, profilu uczestników, deklarowanego standardu organizacji, w tym pod kątem wymagań prawnych.

W celu zbadania rzetelności narzędzia badawczego (kwestionariusz przygotowany jako rezultat badania przygotowawczego) przeprowadzono analizę statystyczną metodą statystyk Alfa Cronbacha. Dodatkowo przeprowadzono także analizę czynnikową, by wyodrębnić grupy czynników ryzyka. Zmienne zostały poddane normalizacji z wykorzystaniem standaryzacji (wykorzystanie średniej i odchylenia standardowego) (Cronbach, 2005).

\section{Identyfikacja czynników ryzyka oraz szacowanie ryzyka w projektach sportowych}

E fektem badania wstępnego była lista 75 czynników C ryzyka sklasyfikowanych w 9 następujących grupach: Bezpieczeństwo (1), Budżet i finanse (2), Informacja (3), Komfort i satysfakcja uczestników (4), Organizacja (5), Pakiet startowy (6), Regeneracja i wsparcie energetyczne (7), Reputacja (8), Środowisko i siła wyższa (9) (tab. 2).

Eksperci podkreślali szczególne znaczenie czynników dotyczących bezpieczeństwa fizycznego uczestników oraz organizacji imprezy biegowej, dlatego zwrócili uwagę na ryzyka związane $\mathrm{z}$ wypadkami na trasie, złym stanem zdrowia uczestników, zagrożenie terrorystyczne i bioterrorystyczne. Uczestnicy badania podnieśli znaczenie ochrony danych osobowych (RODO) oraz cyberbezpieczeństwa związanego ze stroną internetową organizatora i półmaratonu. Jednoznacznie również opowiedziano się za ryzykami dotyczącymi niezapewnienia satysfakcji zawodników, dlatego w ankiecie zostały uwzględnione czynniki dotyczące pakietów startowych, organizacji startu, atrakcyjności trasy czy organizacji depozytu.

Zdefiniowane czynniki ryzyka zostały wykorzystane do szacowania ryzyka, a ich grupowanie miało charakter umowny, uzgodniony z ekspertami. W celu oceny kwestionariusza badawczego wykorzystano analizę rzetelności z użyciem statystyki Alfa Cronbacha. Wartość wskaźnika na poziomie 0,911 (liczba pozycji 27) stanowi potwierdzenie spójności wewnętrznej narzędzia badawczego.

$\mathrm{Na}$ podstawie średnich wartości ryzyka, stosując kryterium osypiska (screeplot), wydzielono 5 grup czynników ryzyka (tab. 3) - najważniejsze (11) (tab. 4), mniej ważne (16) (tab. 5), a także neutralne oraz mało ważne i nieistotne.

Tabela 3. Grupy czynników ryzyka w zakresach średnich

\begin{tabular}{|c|l|c|c|}
\hline \multirow{2}{*}{ \# czynników } & \multicolumn{2}{c|}{ zakres średnich } \\
\cline { 3 - 4 } & \multicolumn{2}{|c|}{$\begin{array}{c}\text { do } \\
\text { odo }\end{array}$} \\
\hline 11 & najważniejszych & 5,10 & 6,23 \\
\hline 16 & mniej ważnych & 3,53 & 4,94 \\
\hline 17 & neutralnych & 3,15 & 3,92 \\
\hline 7 & mało ważnych & 2,49 & 2,94 \\
\hline 9 & nieistotnych & 1,34 & 2,25 \\
\hline
\end{tabular}

Źródło: opracowanie własne

Pośród czynników najważniejszych respondenci wskazali m.in. na czynniki związane z finansowaniem półmaratonu, zagadnieniami organizacyjnymi i bezpieczeństwem odnoszącym się do zagrożeń terrorystycznych, cyberbezpieczeństwa oraz stanu zdrowia uczestników. W grupie najważniejszych czynników znalazło się także ryzyko kolizji terminu $\mathrm{z}$ inną konkurencyjną imprezą sportową.

Tabela 4. Najważniejsze czynniki ryzyka

\begin{tabular}{|c|c|c|c|}
\hline Kod & Czynnik ryzyka & Średnia & $\begin{array}{l}\text { Odchylenie } \\
\text { standardowe }\end{array}$ \\
\hline 2.2. & Niedostateczne wpływy ze środków sponsorów & 6,23 & 2,52 \\
\hline 5.16. & Ograniczone zasoby personalne & 6,02 & 1,49 \\
\hline 5.8. & Problemy dotyczące organizacji, terminu itd., np. z lokalną społecznością & 6,01 & 2,33 \\
\hline 9.7. & Siła wyższa & 5,94 & 1,88 \\
\hline 2.5 & Kolizja terminu z inną konkurencyjną imprezą & 5,84 & 0,91 \\
\hline 3.4 . & Niezamierzone ujawnienie danych osobowych & 5,78 & 2,48 \\
\hline 5.14 . & Niesprawny pomiar czasu & 5,75 & 2,54 \\
\hline 2.1 & Zbyt małe wpływy z opłat startowych & 5,71 & 1,84 \\
\hline 5.9. & Opóźniony start & 5,23 & 1,01 \\
\hline 5.17. & Niedostosowanie przepustowości trasy biegowej do liczby uczestników & 5,13 & 1,70 \\
\hline 2.3 & Brak płynności finansowej & 5,10 & 2,67 \\
\hline
\end{tabular}

Źródło: opracowanie wtasne 
Otrzymane wyniki dostarczyły informacji na temat obszarów krytycznych dla organizacji imprez sportowych, na których w pierwszej kolejności powinni skupić się organizatorzy i które powinni uwzględniać na każdym etapie podejmowania decyzji. Istotnymi czynnikami ryzyka są problemy z finansowaniem oraz organizacją imprezy (ograniczone zasoby personalne). Dla startujących i widzów to wielkie święto, jednak cykliczne imprezy dezorganizują życie społeczności lokalnej. Z kolei fakt, że jest wiele imprez, a sezon startowy ograniczony jest kalendarzem, często prowadzi to do spadku liczby uczestników z uwagi na konkurencyjne imprezy biegowe organizowane w tym samym lub zbliżonym czasie.

Po wyborze czynników ze średnią oceną ryzyka na poziomie 4,1 bądź większym dokonano odcięcia (cut-off) z uwzględnieniem oceny merytorycznej; nie uwzględniono wszystkich zmiennych na podstawie analizy średnich. Analizując wykres średnich poszczególnych zmiennych ułożonych malejąco, można było potraktować ten wykres jako wykres osypiska (screeplot) i w konsekwencji nie uwzględniać zmiennych, które miałyby dla respondentów marginalne znaczenie, a jednocześnie po standaryzacji, mogłyby skutecznie wpłynąć na wyniki grupowania. Dodatkowo sklasyfikowano czynniki ryzyka pod kątem prawdopodobieństwa ich wystąpienia $\mathrm{w}$ trzech grupach $-\mathrm{z}$ oceną prawdopodobieństwa 2 lub wyższą (14 czynników), czyli najbardziej prawdopodobnych, $\mathrm{z}$ oceną pomiędzy 1,2 i 2 (50 czynników) oraz 12 najmniej prawdopodobnych czynników ryzyka, które mogą wystąpić tylko teoretycznie (średnia 1,19 i mniejsza).

Respondenci uznali za najbardziej prawdopodobne wystąpienie czynników związane $\mathrm{z}$ budżetem półmaratonu i osiąganiem założonych celów finansowych, jak również dotyczących bezpieczeństwa fizycznego uczestników biegu (wtargnięcie osoby postronnej na trasę biegu), ochroną danych (cyberatak, ujawnienie danych osobowych) oraz organizacji (startu, mety, odbioru pakietów startowych).

Lista czynników ryzyka, stanowiąca efekt prezentowanego badania, powinna być wykorzystywana jako baza wobec ukierunkowania dodatkowych zabezpieczeń obniżających ryzyko organizacji imprez sportowych do poziomu akceptowalnego. Dla podejmowania celowych decyzji związanych $\mathrm{z}$ organizacją imprezy zasadne jest uwzględnienie czynników najbardziej prawdopodobnych, jak również o największym wpływie (skutku).

\section{Podsumowanie}

7 arządzanie ryzykiem jest wskazywane przez wielu autorów jako kluczowy element zarządzania projektami. Autorzy poświęcili szczególną uwagę szacowaniu ryzyka w organizacji półmaratonów oraz określili kierunkowe działania

Tabela 5. Mniej ważne czynniki ryzyka

\begin{tabular}{|c|c|c|c|}
\hline Kod & Czynnik ryzyka & Średnia & $\begin{array}{l}\text { Odchylenie } \\
\text { standardowe }\end{array}$ \\
\hline 6.1. & Nieatrakcyjny pakiet startowy & 4,94 & 1,54 \\
\hline 8.1. & Nieprzychylne informacje medialne o zasięgu ogólnokrajowym & 4,87 & 1,74 \\
\hline 4.4. & Brak możliwości odbierania pakietów startowych w dniu zawodów & 4,77 & 1,99 \\
\hline 5.13 . & Brak zaangażowania wolontariuszy & 4,69 & 0,99 \\
\hline 5.5. & Niewłaściwa organizacja startu - tłok po rozpoczęciu biegu & 4,68 & 1,05 \\
\hline 3.5. & Kradzież danych osobowych & 4,64 & 1,39 \\
\hline 8.5. & Zbyt mała liczba uczestników (zbyt małe zainteresowanie) & 4,57 & 1,79 \\
\hline 4.7. & Zbyt wąska trasa biegowa; przewężenia & 4,53 & 1,57 \\
\hline 5.1. & Błędne oznaczenie trasy biegowej & 4,44 & 1,74 \\
\hline 5.12 . & Zbyt mała liczba wolontariuszy & 4,43 & 1,45 \\
\hline 1.1. & Poważne incydenty na trasie & 4,33 & 1,14 \\
\hline 7.3. & Niedostateczna ilość wody w ramach punktów regeneracji & 4,32 & 1,72 \\
\hline 1.2. & Wtargnięcie osoby postronnej na trasę biegowa & 4,29 & 1,21 \\
\hline 4.2. & Zła organizacja przechowalni rzeczy & 4,17 & 0,92 \\
\hline 8.6. & Konkurencyjna impreza lokalna & 4,16 & 2,36 \\
\hline 1.5. & Atak terrorystyczny (wybuch, strzelanina, taranowanie samochodem) & 4,15 & 1,89 \\
\hline 1.7. & Niedostateczne zabezpieczenie medyczne & 4,13 & 1,55 \\
\hline 7.4. & Niedostateczna ilość napojów izotonicznych w ramach punktów regeneracji & 3,53 & 1,03 \\
\hline
\end{tabular}

Źródło: opracowanie wtasne 
mitygujące ryzyka o charakterze istotnym. Analiza literatury potwierdziła znaczenie zarządzania ryzykiem w zarządzaniu projektami (Głodziński, 2014, s. 35-38; Grzeszczyk, 2016, s. 97-99), w tym także projektami sportowymi (Leopkey, Parent, 2009a; Linton, Valentin, 2018), a jednocześnie niedocenianie tego elementu (Moyle i in., 2014, s. 97).

Przedstawione $\mathrm{w}$ niniejszej publikacji badania po raz pierwszy obejmowały systemowe, metodyczne szacowanie ryzyka organizacji półmaratonów w Polsce i pozwoliły na wypracowanie bazy 75 czynników ryzyka sklasyfikowanych w 9 kategoriach i uszeregowanie ich według istotności dla organizatorów (uczestników badania). Dokonano szacowania ryzyka $\mathrm{z}$ uwzględnieniem skutku oraz prawdopodobieństwa wobec każdego z czynników ryzyka. Największe ryzyka to finansowanie imprezy, zagadnienia organizacyjne (wolontariat, lokalna społeczność, termin półmaratonu) oraz siła wyższa; wcześniej postrzegana jako problemy z pozwoleniem, upał czy porywisty wiatr - dotyczące pojedynczych imprez; teraz słuszność wskazania potwierdza pandemia COVID-19 oraz formalne zakazy organizacji imprez sportowych w skali całego świata. Badania pozwoliły na pozytywną weryfikację hipotez badawczych. Eksperci nie przewidzieli jednak pandemii (czy innego globalnego czynnika) i związanych z tym zakazów formalnych i konieczności odwołania imprez sportowych (co nastąpiło w 2020 r.). Ewentualna organizacja zawodów wirtualnych traktowana jest jako namiastka tradycyjnej rywalizacji i nie jest postrzegana jako działanie, które może zastąpić imprezy w oczekiwanym klasycznym kształcie. Organizatorzy podkreślają także obawy o zagadnienia ochrony danych osobowych uczestników (kradzież tożsamości wskutek niedostatecznego zabezpieczenia danych), a także na warunki startu i na trasie pod kątem bezpieczeństwa oraz komfortu uczestników. Co ciekawe, organizatorzy nie obawiają się wypadków śmiertelnych i kontuzji uczestników czy ataków terrorystycznych. Skoncentrowanie prac wokół rezultatów szacowania ryzyka (kolejnych edycji) daje podstawę do podejmowania najwłaściwszych decyzji na rzecz bezpieczeństwa i jakości imprez sportowych. Kompleksowy charakter badania pozwala na wykorzystanie zaproponowanej metodyki przez każdego z organizatorów masowych imprez biegowych, chociaż specyfika wielu $\mathrm{z}$ nich jest inna, a w szczególności - kontekst (czynniki wewnętrzne oraz zewnętrzne) jest zmienny, dlatego konieczna jest każdorazowa weryfikacja czynników ryzyka.

dr hab. inż. Jacek Łuczak, prof. uczelni

Uniwersytet Ekonomiczny w Poznaniu

Instytut Zarządzania

ORCID: 0000-0002-8990-7260

e-mail: jacek.luczak@ue.poznan.pl

\author{
dr inż. Małgorzata Miśniakiewicz \\ Uniwersytet Ekonomiczny w Krakowie \\ Kolegium Nauk o Zarządzaniu i Jakości \\ ORCID: 0000-0002-1282-2840 \\ e-mail: misniakm@uek.krakow.pl
}

\section{Bibliografia}

[1] Albrecht A. (2014), Logistyka imprez sportowych na przykładzie Mistrzostw Europy Juniorów 2013 w Poznaniu $w$ plywaniu, pływaniu synchronicznym i skokach do wody (wybrane aspekty organizacji zawodów), „Logistyka”, Nr 5, s. 67-70.

[2] Ammon R., Brown M. (2010), Risk Management Process, [in:] D.J. Cotton, J.T. Wolohan (eds.), Law for Recreation and Sport Managers (4 ed.), Kendall Hunt Publishing Company, Dubuque, pp. 288-300.

[3] Beck K. et al. (2001), Manifesto for Agile Software Development, „The Agile Alliance”, https://agilemanifesto.org, access date: 22.06.2018.

[4] Boo S., Gu H. (2010), Risk Perception of Mega -events, „Journal of Sport \& Tourism”, Vol. 15, No. 2, pp. 139-161.

[5] Bowdin G., Allen J., O'Toole W., Harris R., McDonnell I. (2006), Events Management, Routledge, London.

[6] Bukłaha E. (2019), Menedżerski controlling projektów - koncepcje i wyniki badań, OW SGH, Warszawa.

[7] Chadam J. (2016), Zarządzanie ryzykiem $w$ projektach infrastrukturalnych: studium przypadku, „Przegląd Organizacji”, Nr 7, s. 34-40.

[8] Cronbach J. (2005), Współczynnik Alfa, a struktura wewnętrzna testów, [w:] J. Brzeziński (red.), Trafność i rzetelność testów psychologicznych, Wybór tekstów, Gdańskie Wydawnictwo Psychologiczne, Gdańsk.

[9] Czkór D. (2014), Zapewnienie bezpieczeństwa uczestnikom imprez biegowych na przykładzie Cracovia Maraton, [w:] K. Nessel, E. Wszendybył-Skulska (red.), Młodzi o sporcie 2014. Bezpieczeństwo i organizatorzy imprez sportowych, Katedra Zarządzania w Turystyce, Uniwersytet Jagielloński, Kraków, s. 39-62.

[10] Dzięgiel A., Lubowiecki-Vikuk A.P. (2013), Imprezy biegowe jako specyficzny rodzaj wydarzeń sportowych, „Zeszyty Naukowe. Turystyka i Rekreacja”, Nr 2(12), s. 119-135 .

[11] Głodziński E. (2014), Zarządzanie projektami w warunkach niepewności - zakres i metodyka, „Przegląd Organizacji”, Nr 7, s. 34-40.

[12] Grzeszczyk T.A. (2016), Nowe metody oceny ryzyka w projektach publicznych, „Public risk management. T. 2, Wybrane zagadnienia”, s. 95-103.

[13] Hanstad D.V. (2012), Risk Management in Major Sporting Events: A Participating National Olympic Team's Perspective, „Event Management”, Vol. 16, No. 3, pp. 189-201.

[14] Helms K. (2011), Risk Management in Running Race Events, http://www.sportrisk.com/2011/07/risk-manage ment-in-running-race-events, access date: 20.03.2018.

[15] Hitchings R., Latham A. (2017), How 'Social' is Recreational Running? Findings from a Qualitative Study in London and Implications for Public Health Promotion, „Health Place”, Vol. 46, pp. 337-343.

[16] Idzikowski W., Głowicki P. (2016), Wykorzystanie podejścia zwinnego $z$ branży IT do tworzenia modeli biznesowych organizacji sportowych, „Informatyka Ekonomiczna", Nr 4(42), s. 20-29.

[17] ISO 31000:2018, Risk Management - Principles and Guidelines, International Standard Organization. 
[18] Leopkey B., Parent M.M. (2009a), Risk Management Issues in Large-scale Sporting Events: A Stakeholders Perspective, „European Sport Management Quarterly”, Vol. 9, No. 2, pp. 187-208.

[19] Leopkey B., Parent M.M. (2009b), Risk Management Strategies by Stakeholders in Canadian Major Sporting Events, „Event Management”, Vol. 13, No. 3, pp. 153-170.

[20] Linton L, Valentin S. (2018), Running with Injury: A Study of UK Novice and Recreational Runners and Factors Associated with Running Related Injury, ,Journal of Science and Medicine in Sport", Vol. 21, No. 12, pp. 1221-1225.

[21] Łuczak J., Miśniakiewicz M. (2011), Risk Management as Basic of Management System on Polish Government Offices Example, „Studia Oeconomica Posnaniensia - poprzedni tytuł: Zeszyty Naukowe Uniwersytetu Ekonomicznego (AE) w Poznaniu", No. 217, pp. 183-193.

[22] Łuczak J., Miśniakiewicz M. (2014), Niektóre czynniki sukcesu organizatorów i uczestników imprez biegowych, [w:] M. Lotko, J. Żuchowski, R. Zieliński (red.), Wybrane aspekty zarządzania jakościa $i$ środowiskiem, Wydawnictwo Naukowe Instytutu Technologii Eksploatacji - PIB, Radom, s. 89-98.

[23] Miller J., Wendt J., Young P. (2010), Fourth Amendment Consideration and Application of Risk Management Principles for Pat-Down Searches at Professional Football Hames, „Journal of Legal Aspects of Sport”, Vol. 20, pp. 107-134.

[24] Moyle B., Kennelly M., Lamont M. (2014), Risk Management and Contingency Planning in Events: Participants" Reaction to the Cancellation of Ironman New Zealand 2012, „International Journal of Event Management Research", Vol. 8, No. 1, pp. 94-106.

[25] Petridis L. (2015), Greece: Mass Running: a New Trend from Ancient Times? [in:] J. Scheerder, K. Breedveld, J. Borgers, (eds.), Running across Europe: The Rise and Size of One of the Largest Sport Markets, Palgrave Macmillan, Basingstoke, pp. 140-162.

[26] Piekarz M., Jenkins I., Mills P. (2015), Risk and Safety Management in the Leisure, Events, Tourism and Sports Industries, CABI.

[27] Polska Biega, www.maratonypolskie.pl, data dostępu: 1.06.2019 r.

[28] Reid S., Ritchie B. (2011), Risk Management: Event Managers' Attitudes, Beliefs, and Perceived Constraints, „Event Management”, Vol. 15, No. 4, pp. 329-341.

[29] Scheerder J., Breedveld K., Borgers J. (eds.), (2015a), Running across Europe: The Rise and Size of One of the Largest Sport Markets, Palgrave Macmillan, London.

[30] Scheerder J., Breedveld K., Borgers J. (2015b), Who is Doing a Run with the Running Boom? The Growth and Governance of One of Europe's Most Popular Sport Activities, [in:] J. Scheerder, K. Breedveld, J. Borgers, (eds.), Running across Europe: The Rise and Size of One of the Largest Sport Markets, Palgrave Macmillan, Basingstoke, pp. 1-27.

[31] Shipway R., Holloway I., Jones I. (2013), Organizations, Practices, Actors, and Events: Exploring Inside the Distance Running Social World, „International Review for the Sociology of Sport", Vol. 48, No. 3, pp. 259-276.
[32] Silvers J. (2008), Risk Management for Meetings and Events, Routledge, New York.

[33] Spałek S. (2018), Rozpoznawalność i stosowanie zwinnego zarzadzania projektami w polskich przedsiębiorstwach $w$ świetle badań empirycznych, "Zeszyt Naukowy SGH”, Nr 159, s. 155-172.

[34] Thangaratinam S., Redman C.W.E. (2005), The Delphi Technique. Education. The Obstetrician, „Gynaecologist”, Vol. 7, pp. 120-125.

[35] Toohey K., Taylor T. (2008), Mega Events, Fear, and Risk: Terrorism at the Olympic Games, „Journal of Sport Management", Vol. 22, pp. 451-469.

[36] Wyrozębski P. (2019), Biuro Zarządzania Projektami (PMO), Polskie Wydawnictwo Ekonomiczne S.A., Warszawa.

\section{Identification of Risk Factors and Risk Assessment in the Project of Sports Events Organising}

\section{Summary}

For the last decade we have observed the popularity of the growth and professionalisation of amateur running in Poland. The number of running events is increasing. Moreover, runs must be managed professionally according to the project management methodology due to competition. A relevant literature analysis has confirmed the importance of risk management in project management, including sports projects within which this aspect is often underestimated.

The paper presents the results of research aimed at identifying risk factors and estimating the risks associated with the organisation of half marathons in Poland. The research presented in this publication for the first time included systemic, methodical risk estimation for long-distance runs in Poland and allowed the base of dozens of risk factors to be developed and grouped. Risk estimation has been conducted taking into account the effect and likelihood of each of the risk factors. The biggest risks are event funding, organisational issues, and force majeure. Organisers also highlight concerns about the protection of participants' personal data (identity theft due to insufficient data security), as well as the participation and course-related conditions in the context of participants' safety and comfort. Focusing the research on the results of risk estimation (of subsequent editions) provides the basis for making the most appropriate decisions for increasing the safety and quality of sporting events. The comprehensive nature of the study allows for the use of the proposed methodology by each of the organisers of mass running events (and more widely - sports events).

\section{Keywords}

risk management, risk management in sport, risk factors, risk mitigation 